Seminário de Pesquisa

Programa de Pós-Graduação

Design FAU USP

\title{
Entendendo os processos criativos envolvidos no design de interfaces digitais generativas
}

\author{
Caio Barrocal Fernandes, Clice de Toledo Sanjar Mazzilli \\ design generativo; design computacional; design digital; arte \\ generativa; interação humano-computador
}

Os algoritmos generativos vêm sendo empregados pela arte e pelo design na concepção de formas e experiências inovadoras, como instalações interativas e identidades visuais flexíveis. No campo do design digital, esses algoritmos podem contribuir para o projeto de interfaces capazes de responder em tempo real a estímulos do ambiente e dos usuários, possibilitando que apps, sites, totens e displays públicos tenham seu estado alterado conforme a leitura que

Curso

Mestrado

\section{Linha de Pesquisa}

Design: Processos e Linguagens

\section{Caio Barrocal Fernandes}

É graduado em Ciência da Computação pela USP (2018) e, atualmente, é aluno do mestrado em Design na mesma instituição. Pesquisa a intersecção entre a computação e o design, e como algoritmos generativos podem ser empregados no projeto de interfaces digitais. Trabalha como UX Designer desde 2017.

e-mail: caio.barrocal@usp.br Lattes: http://lattes.cnpq. br/2462400036225390

\section{Clice de Toledo Sanjar Mazzilli}

Graduada em Arquitetura

e Urbanismo pela FAU USP

(1984), onde realizou mestrado, doutorado e livre-docência na área de Programação Visual. Leciona no Departamento de Projeto da FAU USP, desde 2001 e atualmente coordena o Programa de Pós-graduação em Design e o Laboratório de Programação Gráfica.

e-mail: clice@usp.br

Lattes: http://lattes.cnpq. $\mathrm{br} / 9635315172253349$

Orcid: https://orcid.org/0000-

0002-6903-9099 fazem dos locais em que estão. Existem, entretanto, poucas obras a respeito de como esses algoritmos são empregados em projetos de design digital, sobretudo no Brasil, e, portanto, a pesquisa propõe uma investigação qualitativa baseada em estudos de casos para descrever o processo criativo empregado por designers profissionais neste tipo de projeto. A pesquisa toma como objetivos específicos investigar as principais etapas de processos criativos propostas por Sawyer (2012) e Lubart (2007), e busca entender a aplicabilidade de pressupostos teóricos levantados acerca do projeto de interfaces digitais generativas em cada uma delas, por meio de estudos de casos como os projetos "BRUTE", de Patrik Hübner (2018), e os pôsteres digitais generativos de Rebelo et al. (2019). A unidade de análise - caso, será o processo criativo pelo qual passou um designer na elaboração de um projeto específico, objeto a ser elucidado por técnicas como entrevistas semi-estruturadas e análises de portfólio e de esboços. Como existem poucos designers brasileiros que trabalham com interfaces digitais generativas, e uma vez que os métodos escolhidos pressupõem acesso aos designers e a documentos sobre os projetos realizados, a principal dificuldade da pesquisa, em função da pandemia de COVID-19, vem sendo a seleção dos casos a serem estudados. 


\title{
Understanding creative processes employed in the design of digital generative interfaces
}

\author{
Caio Barrocal Fernandes, Clice de Toledo Sanjar Mazzilli
}

\author{
generative design; computational design; digital design; generative \\ art; human-computer interaction
}

Currently, generative algorithms are employed by artists and designers in the creation of innovative shapes and experiences, such as interactive installations and flexible visual identities. Within digital design, these algorithms may contribute to the design of interfaces capable of answering, in real time, to users' inputs and environmental stimuli, enabling apps, websites and public displays to change their state according to the place in which they are. However, there are few works discussing how these algorithms can be employed in digital design projects, especially in Brazil, and therefore this research proposes a qualitative investigation based on case studies to describe the creative process designers employ on this kind of project. Research's specific goals are to investigate the main phases of creative processes proposed by Sawyer (2012) and Lubart (2007), while trying to understand the validity of certain theoretical assumptions about the design of digital generative interfaces in each one of them. For this, we will study cases such as Patrik Hübner's "BRUTE" (2018), and the digital generative posters created by Rebelo et al. (2019). The unity of analysis - case, will reveal the creative process employed by a certain designer during the creation of a certain project, object to be elucidated by methods such as interviews, and analyses of portfolio and sketches. Since there are few Brazilian designers currently working with digital generative interfaces, and once the chosen methods require access to designers and their projects, the major difficulty, even more complicated due to the COVID-19 pandemics, has been choosing the cases to be studied.

\section{Referências | References}

LUBART, T. 2007. Psicologia da Criatividade. Porto Alegre: Penso.

SAWYER, R. K. 2012. Explaining Creativity: The Science of Human Innovation. New York: OUP US.

REBELO, S. et al. 2019. Designing Posters Towards a Seamless Integration in Urban Surroundings: A Computational Approach. ARTECH 2019.

ARTECH 2019. HÜBNER, P. 2018. Brute: A brand crafted by the elements. In: HÜBNER, P. Patrik Hubner: Portfolio. 〈https://www.patrik-huebner.com/ portfolio-item/brute-data-driven-wine-brand/>, 07/10/2020.

Program in Design and the

Graphic Programming Lab and is responsible for the Double Degree Agreement between FAU USP and Politecnico di Milano (Scuola del Design).

e-mail: clice@usp.br

Lattes: http://lattes.cnpq.

$\mathrm{br} / 9635315172253349$

Orcid: https://orcid.org/0000-

0002-6903-9099 